Peter Zieme

\title{
An Old Uighur Fictional Letter Supposedly Written by Prince Gautama from a Fragment in the Serindia Collection at the IOM, RAS
}

Abstract: In this paper the Old Uighur fragment SI 4bKr 11 (SI 4028) of the Serindia Collection at the Institute of Oriental Manuscripts, the Russian Academy of Sciences is edited together with notes. Its content are rather peculiar and shed some light on the attitude of Uighur monks towards their Buddhism.

Key words: Old Uighur, Buddhist culture, fiction, rare words

The recto side of fragment SI 4bKr 11 (SI 4028) of the Serindia Collection at the Institute of Oriental Manuscripts (IOM) of the Russian Academy of Sciences is part of a copy of the 菩薩瓔珞本業經 Pusa yingluo benye jing ("Gem-Necklace Scripture of Bodhisattvas") attributed to Zhu Fonian. ${ }^{1}$

The verso side is a remarkable testimony to the activities of Old Uighur Buddhist monks. From left to right the leaf can be divided into four sections. $\mathbf{A}$ is the concluding passage of an Old Uighur Buddhist text, $\mathbf{B}$ is a colophon, $\mathbf{C}$ is a part of a loan contract, and $\mathbf{D}$ is the transcription of a Chinese phrase in Uighur script. Before coming to $\mathbf{A}$, which is the main subject of this paper, I shall discuss the other sections briefly.

\section{Section B (colophon)}

Section B was introduced by D. Matsui. ${ }^{2}$ The text of this colophon can be read as follows.

(10) kwyskw yyl 'ltync 'y pyr ynkyq' pw t'vä'c kwyn t' mn

(10) küskü yıl altınč ay bir yayıka bo tavgač kön-tä m(ä)n

(11) $<t>$ t' qycwq twtwnk qy 'yrykyp 'wlwrwp 'yky k'zyk ky

(11) $<t>$ takıčok tutuy k(1)y-a irikip olurup iki käzig-k(i)y-ä

(C) Peter Zieme, Free University, Berlin and Tōyō Bunko, Tokyo

${ }^{1}$ T. 1485 , vol. 24, pp. 1014b12-29.

${ }^{2}$ Further notes in MATSUI 2004, 58, 61, 66. 
(12) py[ ]dym cyn 'wl 'zwk ym' 'rm'z 'wl typ pytydym cyn t'kynwr mn

(12) bitidim čın ol äzüg ymä ärmäz ol tep bitidim čın täginür m(ä)n

"In the year of mouse, in the sixth month, on the first day. On this Chinese scroll I, Takıčok(?) ${ }^{3}$ Tutun K(1)ya, sitting about lazily, ${ }^{4}$ only wrote a couple of lines. It is true; it is not wrong. It is true, I affirm."

\section{Section C (loan contract)}

(13) qwyn yyl 'wycwne "y vyty ykrmy k' m'nk'

(13) koyn y1l üčünč ay yeti ygrmikä maja

(14) smpwdw twtwnk q' 'syq q' kwymws krk'k

(14) s(a)mbodu tutun-ka asıg-ka kümüš kärgäk

"Sheep year, third month, on the seventeenth. I, S(a)mbodu Tutuy, was in need of silver on interest."

\section{Section D}

D is a separate section (lines 15 to 19). This passage edited by M. Shōgaito ${ }^{5}$ contains the Chinese phrase 四種族性清浄諸勝刹利王帝 followed by a transcription in Uigur script and an Old Uighur translation.

The first attempt at translating the Chinese phrase - tegmä tört türlüg tözüg ugušs kitärtäči $t^{6}$ (11. 15-16) — was determined to be wrong, without a mark of deletion. In his new attempt the writer started with a transcription of the Chinese sounds into Uighur script, after which he translated the phrase. Here I present the text in the following table.

${ }^{3}$ t'qycwq or t'rnycwq. I follow Matsui's reading although it is not definitive.

${ }^{4}$ Translated as kokoro-o itame 心を痛め) “in sorrow” (MATSUI 2004, 53, 66). The verb irik- (erik-?, ED, 226a) has the meaning "to be disgusted, bored". M. Erdal (OTWF, 366) reminds of Mạ̣mūd al-Kāšgarı̄'s ir- "to be lonely", but Clauson combines ir- and irik-. In Kirgiz (JudACHIN 1965, 461b) the verb irik- has two meanings "to be bored" and "to be lazy". I think that the latter meaning fits the phrase above, expressing the self-deprecating attitude of scribes: "sitting about lazily I only wrote a couple of lines", or in a more natural rendering as Nicholas Sims-Williams suggested to me: "owing to my laziness I only wrote a couple of lines". The expression "two lines" is probably not meant literally: it should rather be interpreted as "a couple of lines".

${ }^{5}$ ShŌGAITO 1997, 28-29. Mentioned in MATSUi 2010, 700.

${ }^{6}$ Emended to ta[rkartačı $]$.

${ }^{7}$ For details see SHŌGAITO 1997, 28-29. In lines 3 and 10 the characters were not transcribed. Line 12: The phrase beginning with töpüdä abižek "abhișeka on the head" definitely refers to the emperor or ruler (wangdi), cf. RöHRBORN 2015, 5-6. 
(1)

$\begin{array}{ccc}\text { Pinyin } & \begin{array}{c}\text { Transcription } \\ \text { in Uighur script }\end{array} & \text { OU translation } \\ \text { si } & s y & \text { tört } \\ \text { zhong } & c w n k & \text { türlüg } \\ z u & - & \text { tözlüg } \\ \text { ugušluglarnin } \\ \text { arasinta }\end{array}$

The ksatriya is the name of the second in the system of the four castes in India, but in the phrase above it is placed first. This deviates from the traditional sequence of the four castes, i.e. brähmana (priests), kṣatriya (military), vaiśya (farmers, traders), śüdra (serfs), but agrees with a passage in the Old Uighur Insadi-sütra: kištirik braman uz tarıǧ̀ bo tört ugušluglar "those who belong to the four castes, i.e. kșatriya, brāhmana, artisans, farmers". 8 While the artisans are chosen as representatives of the third caste, the farmers were regarded as the lowest caste. In at least four Chinese texts, too, the sequence begins with ksatriya: T. 374, T. 375, T. 397, T. $1763 .^{9}$

\section{Section A}

Finally, the first section (A) on the verso side of the fragment is the most interesting and most difficult.

\section{Transliteration and transcription}
(01) [
] mn pww ${ }^{10}$ pys ' 'šwn nwk ywl 'ycyn t' k[
(01) [ ] $m(\ddot{a}) n$ bo beš ažun-nuy yol ičin-tä-k[i

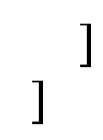

\footnotetext{
${ }^{8}$ BT III 119.
}
${ }^{9}$ T. 374 , vol. 12, p. $372 \mathrm{a} 2$, T. 375 , vol. 12 , p. $611 \mathrm{~b} 24$, T. 397, vol. 13, p. 359b8, T. 1763 , vol. 37, p. $390 \mathrm{~b} 4$.
${ }^{10}$ Peculiar spelling pww for bo "this". 

$\mathrm{k}^{\prime}[$

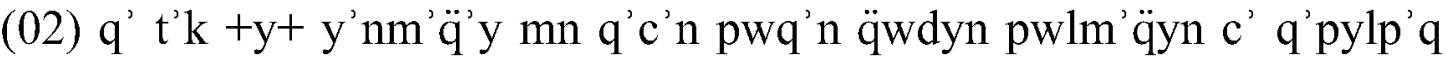

(02) -ka-tägi yanmagay-m(ä)n kačan burhan kutın bulmagın-ča kapılbak $\mathrm{k}^{\prime}[$

(03) t' $\ddot{q} y$ tydymym q'nkym šswdwt'n' 'ylyk pl'k 'wytwnwr mn ' r'swd ${ }^{2}$ wyk $1 p^{11}$

(03) -tak1 tidimim kayım šudotana elig b(ä)läk ötünür-m(ä)n arašud ọ̈-l(ü)g

(04) kwyk s'cyämy ${ }^{12}$ 'wykwm m'q' m'y q'dwn q' pl'k 'wydwnwr mn pwqwnwm t'qy mwrmw

(04) kök sačımnı ögüm maha-may hatun-ka b(ä)läk ötünür-m(ä)n bogunum-tak1 murmu

(05) -twmwmy kwykwyym ' 'k'm q' dwn q' pwyrl'kym t'ky pwyrl'k swk kwk myn "mr' $\ddot{\mathrm{q}}$

(05) -tum\{um\}n1 kügüyim äkäm hatun-ka *bürläkim-täki *bürläk sụ̈ük-(ü)min amrak

(06) q' dwnwm y’š t'rÿ̈ q̈' p'l'k 'ydwr mn. ''lty ywz twym'n 'yck'k qyrqyyn

(06) hatunum ${ }^{13}$ yaš-tarıh-ka bäläk 1dur-m(ä)n . altı yüz tümän inčgä kırkın

(07) q'nym q' cwt'm'nym ' s'n kwyl'yw 'ytw 'ydwr mn '1ty yyl twynyn

(07) hanım ${ }^{14}$-ka čutamanim äsän-güläyü aytu 1dur-m(ä)n altı y1l tönin

(08) twysq'c'r lyq 'cyq 'mkk 'mk'nwr mn pwq'n qwdyn 'wycwn

(08) dwyšq' '̌́ r'-lıg ačıg ämgäk ämgänür-m(ä)n bu(r)han kutın üčün

(09) pw s'kymwny ny mn 'ydswyn twtwk qy 'pytydym cyn 'wl

(09) bo šakimuni-nı m(ä)n ’ydswyn tutun k(1)y-a bitidim čın ol

\section{Translation}

I will not return into [...] of the ways of these five existences as long as I do not attain Buddhahood.

I offer as a present my diadem on the headgear $k^{\prime}[$ ] to my father, King Śuddhodana.

I offer as a present my räjavarta coloured blue hair to my mother, Queen Mahāmāya.

${ }^{11}$ The word 'wyk lp seems to be written in error for ö $\eta$-lüg.

${ }^{12}$ In s'cyämy the dots cannot be explained.

${ }^{13}$ Written q'dtwn.

${ }^{14}$ As hanim is difficult in this position, it is perhaps better to assume that an $l$-hook was forgotten so that we should read kirkın-larım. 
I send as a present my mumurt on my knuckle to my aunt and my elder sister, the ladies, and my *bürläk bones in my *bürläk to (my) beloved wife Yaśodharā.

Asking about their health, I send my cüdāmani to my 600 times 10,000 tender servant girls.

I suffer the bitter pains of duṣkaracarya $\bar{a}$ suffering through six years for Buddhahood.

I, Idsön Tutuy k(1)ya, wrote this Śākyamuni (text). This is true.

\section{General notes}

The "I" of this fictional letter can be none other than Prince Gautama himself. The actual writer was an Old Uighur monk by name 'ydswyn Tutuy. That name consists of two elements: 'ydswyn + tutuy. The latter is the title dutong 都統 widely used in Buddhist Uighur clerical circles. The first part is certainly also derived from Chinese, but only its second syllable can be identified - coming from quan 泉 “fountain", while the source of the first syllable 'y, which can be read as $i, a y, n i$ and other variants, remains unclear.

What was the purpose of this fictional letter? There is no easy answer. I would like to think of it as a special act of devotion, but possibly it was nothing more than a writing exercise.

\section{Notes on some words}

(02) q'pylp'q may be read *kapılbak. This word can be regarded as the original form of kalpak denoting in Turkic languages "head-cover, hat", etc. ${ }^{15}$ The modern Turkish form reflects a reduction and metathesis from *kapulbak>*kalpbak>kalpak. A similar formation is kögüsbäg in the Old Uighur Family archive. ${ }^{16}$

(03) tidim "crown" 17 is ultimately derived from Greek $\delta \dot{\alpha} \delta \eta \mu \alpha$ "crown" and means here in all probability the ürṇa on Buddha's forehead.

(03-04) "r'swd. If read arašud, this seems to be a previously unnoted spelling of ražvart ${ }^{18}<$ Skt. räjavarta "lapislazuli", the colour of Buddha's uṣnișa, here sač "hair". Cf. ražawrt öylüg kök sačl 19 .

\footnotetext{
${ }^{15}$ Cf. TMEN No. 1506; ED, 584b-585a; ESTJa 1997, 234-236.

${ }^{16}$ UMEMURA 1987, 1. 29; ED, 714b (köküzmek "breastplate").

${ }^{17}$ ED 456b: "the crown which a bride wears on her wedding night", thus recorded in the Family archive, cp. UMEMURA 1987, 1. 87.

${ }^{18}$ KARA 2001, 106.

${ }^{19}$ GENG and KLIMKEIT 1988, 11. 2000-2001 ("his rājavarta-blue hair", mark of Buddha).
} 
(04) Mahāmāya, ${ }^{20}$ Prince Gautama's mother.

(04-05) mwrmwtwm. If one regards the last two letters wm as dittography one gets mwrmwt. The most similar word is mwrmwt in Mainz 724 verso 51 = BT.XXIII.D093: ärtini-lig murmut meaning ratnamālā 寶鬘 “jewel necklace".

(05) kügüy "aunt", this seems to be the first occurrence in an Old Uighur text. ${ }^{21}$ The following word is $\ddot{a} k \ddot{a}$ which can also mean "aunt". ${ }^{22}$ Buddha's maternal aunt and adoptive mother was Mahāpajāpatī Gotamī (Pāli) / Mahāprajāpatī Gautamī (Sanskrit). In a famous story she made a special dress for the Buddha, but the Lord accepted it only after long discussions. This story is told at length in the Old Uighur Maitrisimit nom bitig. ${ }^{23}$

(05) pwyrl'kym t'ky pwyrl'k swk kwk myn. The first word *bürläk (pwyrlwk) denotes something like a head-cover, to be explained from *bürülüg/bürü̈lük "something twisted" < bürül- "to be twisted, folded"24; swk kwk myn = sünük(ü)min "my bones". But the expression as a whole is enigmatic: *bürläkim-täki *bürläk sü̈ük(ü)min "my *bürläk bones in my *bürläk".

(05-06) amrak hatun yaš-tarth "beloved lady Yaśodharā", the wife of Prince Gautama. The name is written in a strange way: y's 's'ryä. In the Maitrisimit nom bitig the spelling is $y^{\prime}$ 'swd' ${ }^{2}{ }^{2} .5$

(06) alt yüz tümän " $600 \times 10,000$ ". In the Maitrisimit nom bitig we find altı tümän kunčuy hatunlar ${ }^{26}$ " 60,000 princess ladies".

(06) ičgäk kırkın, taken as it is, would mean "demon girls", but probably the scribe miswrote the first word, intending to put inc̆gä "tender". The compound inčgä kırkın meaning "servant girls (of the harem)" is known from several texts.

(07) As the paper is torn here, I cannot propose a definite reading, but it seems to be something like cw(n)t' rksy. Although I am assuming cüdàmani here, I should point out that the letters can also be interpreted as *cūdarakșa or *cülalakṣa, if the $l$-hook was forgotten or not written. The latter would mean "the mark of cüdü", Skt. has cüdu-lakșana as the name of the "tonsure", ${ }^{27}$ but that is not something that can be sent as a gift. Skt. cüdāmani is

\footnotetext{
${ }^{20}$ Cf. GENG and KLIMKEIT 1988, 11. 1299, 2226 (maxamaya qatun).

${ }^{21}$ LI 1996.

${ }^{22} \mathrm{ED}, 100 \mathrm{~b}$ "junior (paternal) aunt" and "elder sister", later only "elder sister".

${ }^{23}$ GENG and KLIMKEIT 1988, ch. IV.

${ }^{24} \mathrm{ED}, 365 \mathrm{~b}$.

${ }^{25}$ GENG and KLIMKEIT 1988, 11. 1330, 2456, 2484, 2488; yažotara 1. 2474.

${ }^{26}$ GENG and KLIMKEIT 1988, 1. 2496.

${ }^{27} \mathrm{MW}$, 401a.
} 
the precious stone in the ușnișa. In Old Uighur it is known as the name of a jewel only from the story of Sadaprarudita and Dharmodgata: ${ }^{28}$

anı̀ käntinì tašsnda yana tägirmiläyü

alp tap(i)šguluk čintamani čudamani bilingn(a)mani brahmamanita ulatı ärdinilär üzä

aralašturu etmiš yetirär kat tamlig

adınčlg körklä yetirär kat kalıklarl ısırgalıkları ol : $:^{29}$

"Outside of his city around there were extremely beautiful castles and palaces with seven layers each with seven walls each alternatively ${ }^{30}$ decorated with jewels like cintāmani, cūdōmani, ('sakrā)bhilagnamani, brahmāmani that are difficult to find."

(07) tönin may be a variant of the postposition töni. ${ }^{31}$

(08) twysq' c'r < kt. dușkaracarya "arduous practices", the term for "asceticism", especially that of Buddha when he left home and spent six years leading an ascetic life. ${ }^{32}$ In this spelling in Uighur script we see another rare example of the letter $\mathrm{q}$ for a Sanskrit front $\mathrm{k}^{33}$

\section{Abbreviations}

BT III: Berliner Turfantexte III

BT XXIII: Berliner Turfantexte XXIII

DDB: Digital Dictionary of Buddhism

ED: Etymological Dictionary

ESTJa: Etimologicheskii slovar' tiurkskikh iazykov

GOT: Grammar of Old Turkic

MW: M. Monier-Williams, A Sanskrit-English Dictionary

OTWF: Old Turkic Word Formation

T.: Taishō Buddhist Canon

TMEN: Türkische und mongolische Elemente im Neupersischen

\section{References}

Das uigurische Insadi-sūtra (BT III) 1974: TEZCAN Semih. Das uigurische Insadi-sūtra. Berlin: Akademie-Verlag (Berliner Turfantexte III).

Magische Texte des uigurischen Buddhismus, (BT XXIII) 2005: ZIEME, Peter. Magische Texte des uigurischen Buddhismus. Turnhout: Brepols Publishers (Berliner Turfantexte XXIII).

\footnotetext{
${ }^{28}$ TEKIN 1980, 190.

${ }^{29} 11.070-072$.

${ }^{30}$ OTWF, 816 .

${ }^{31}$ ZIEME 1992.

${ }^{32}$ Cf. DDB; KUDARA and ZIEME 1997, 77.

${ }^{33}$ RÖHRBORN 1988.
} 
Digital Dictionary of Buddhism (DDB) (Charles Muller).

An Etymological Dictionary of Pre-Thirteenth-Century Turkish (ED) 1972: Clauson, Gerard. An Etymological Dictionary of Pre-Thirteenth-Century Turkish. Oxford: Oxford University Press.

Etimologicheskii slovar' tiurkskikh iazykov (ESTJa) 1997: Etimologicheskii slovar' tiurkskikh iazykov. Obshchetiurkskie i mezhtiurkskie osnovy na bukvy " $k$ ", " $k$ ". [Etimological dictionary of the Turkic languages]. Moskva: Nauka, GRVL.

GENG Shimin and KLIMKEIT, Hans-Joachim 1988: Das Zusammentreffen mit Maitreya. Die ersten fünf Kapitel der Hami-Version der Maitrisimit. I-II. Wiesbaden: Harrassowitz.

A Grammar of Old Turkic (GOT) 2004: ERDAL Marcel. A Grammar of Old Turkic. Leiden/ Boston: Brill.

JuDACHIN Konstantin Kuz'mich 1985: Kirgizsko-russkii slovar' [Kyrgyz-Russian dictionary] Frunze: Glavnaia redaktsiia Kirgizskoi Sovetskoi Entsiklopedii.

KARA, György 2001: "Late Medieval Turkic Elements in Mongolian". De Dunhuang à Istanbul. Hommage à James Russell Hamilton. Ed. by L. Bazin and P. Zieme. Turnhout: Brepols Publishers, 73-119.

KudARA Kōgi and ZIEME, Peter 1997: "Two New Fragments of the Larger Sukhāvatīvyūhasütra in Uigur". Nairiku ajia gengo no kenkyū. Studies on the Inner Asian Languages 12. Osaka: The Society of Central Eurasian Studies, 73-82.

Lı Yong-Song 1996: "Kügü kügü̈y "Teyze" Hakkında". Türk Dilleri Araştırmaları Istanbul 6, 71-79.

Matsui Dai 2004: "Notes on the Uigur Secular Documents from the St. Petersburg Collection. Buddhist Monastery of the Toyoq Caves as Revealed from the Texts Related to Monks Sivšidu and Yaqšidu". Papers on the Pre-Islamic Documents and Other Materials Unearthed from Central Asia. Ed. by T. Moriyasu. Kyoto: Hōyū Shoten, 41-70.

MATSUI Dai 2010: "Uigur Manuscripts Related to the Monks Sivšidu and Yaqšidu at "Abita-Cave Temple" of Toyoq". Journal of the Turfan Studies Edited by Academia Turfanica. Essays on The Third International Conference on Turfan Studies. The Origins and Migrations of Eurasian Nomadic Peoples. Shanghai: Shanghai guji shubanshe, 697-714.

A Sanskrit-English Dictionary (MW) 1899: MoniER-WILLIAMS, Monier A Sanskrit-English Dictionary. Oxford: Clarendon Press.

Old Turkic Word Formation (OTWF) 1991: ERDAL, Marcel. Old Turkic Word Formation. A Functional Approach to the Lexicon, I-II. Wiesbaden: Harrassowitz.

RÖHRBORN, Klaus 1988: "Zur Darstellung der Gutturale in den indischen Fremdwörtern des Uigurischen". Central Asiatic Journal 32 (Wiesbaden: Harrassowitz), 232-243.

RÖHRBORN, Klaus 2015: Uigurisches Wörterbuch. Sprachmaterial der vorislamischen türkischen Texte aus Zentralasien - Neubearbeitung - II. Nomina - Pronomina - Partikeln. Band 1: a-asvık, Stuttgart: Franz Steiner Verlag.

ShōGAITO Masahiro 1997: "Chinese Buddhist Texts in Uighur Script (cont'd)". Bulletin of the Society for Western and Southern Asiatic Studies 46. Kyoto, 1-31.

TEKIN, Şinasi 1980: Buddhistische Uigurica aus der Yüan-Zeit. Budapest: Akadémiai Kiadó.

Türkische und mongolische Elemente im Neupersischen (TMEN) 1963-1975: DOERFER G. Türkische und mongolische Elemente im Neupersischen, I-IV. Wiesbaden: Harrassowitz.

UMEMURA Hiroshi 梅村坦 1987: Uiguru monjo "SJ kr.4/638" — konrei sōgi hiyō no kiroku ウイグル文書「SJ kr.4/638」ー- 婚礼・葬儀費用の記録 [A Re-Examination of the Uyghur Document "SJ kr.4/638": An Account Book concerning Weddings and Funerals]. Risshō Daigaku Kyōyōbu kiyō 立正大学教養部紀要 [The Journal of Rissho University Liberal Arts Faculty] 20. Tokyo: Risshō Daigaku, 35-87. 
TWYNY: Zieme, Peter 1992: “= töni, eine bisher verkannte Postposition des Alttürkischen Altorientalische Forschungen Berlin: Akademie-Verlag 19, 160-165.

Taishō: 大正新脩大蔵經 Taishō shinshu daizōkyō [Taishō Revised Tripitaka]. Ed. by Takakusu Junjirō̄ 高楠順次郎. Tōkyō: Taishō Issaikyō Kankōkai 大正一切經刊行會, 1924-1934.

Photographs of SI 4bKr 11 (SI 4028)

//Photograph 1//

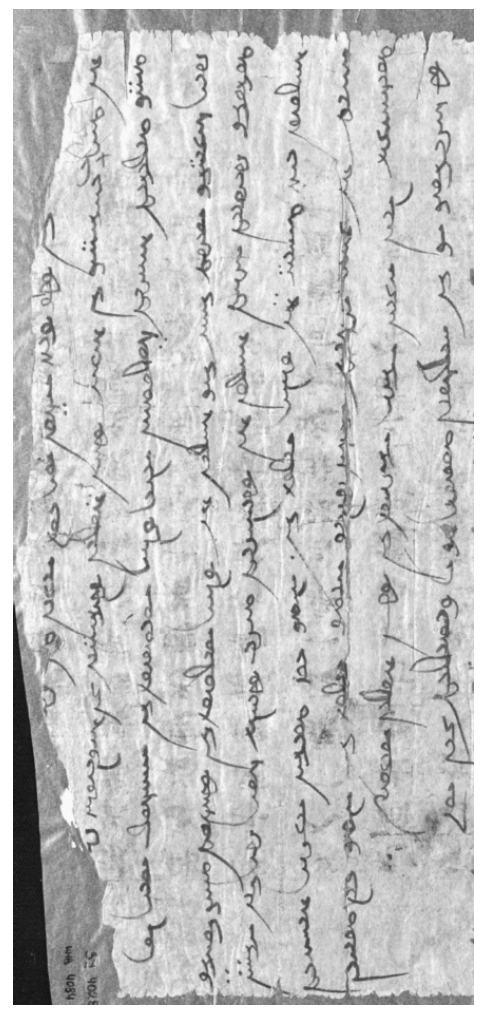

Section A
//Photograph 2// //Photograph 3//

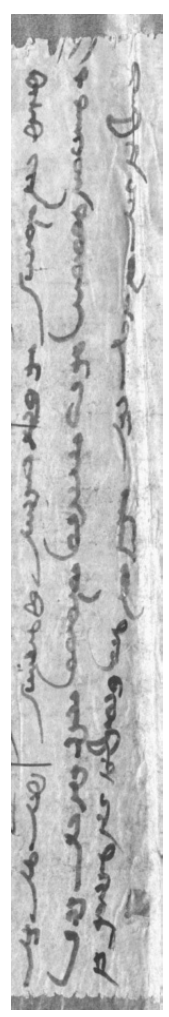

Section B

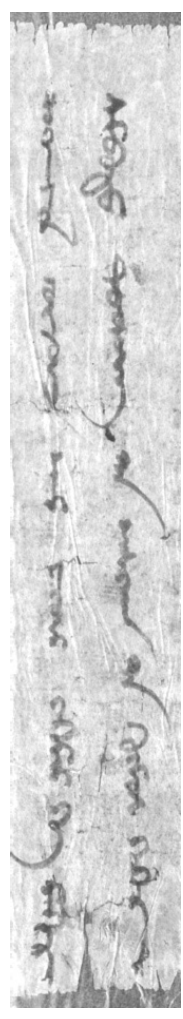

Section $\mathrm{C}$
//Photograph 4//

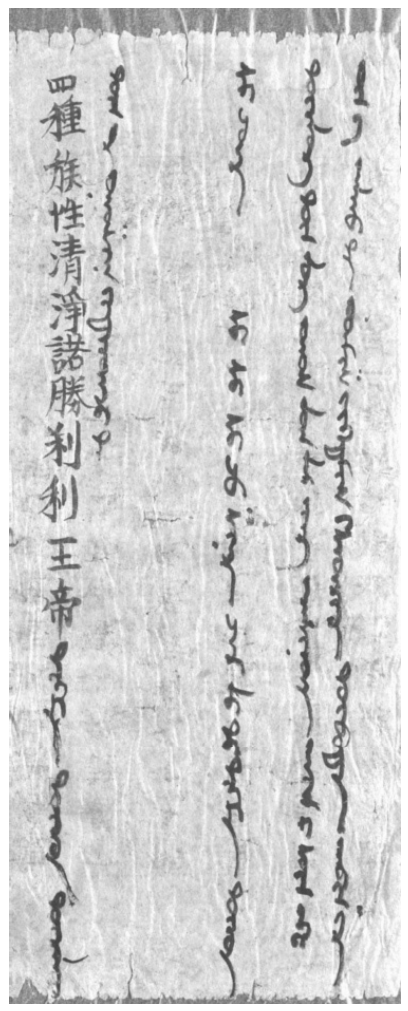

Section D 